\title{
Can sustainable development be achieved if geology is ignored?
}

\author{
Dr Katherine R. Royse *, Dr Vanessa J. Banks, Stephanie H. Bricker and Andrew P. \\ Marchant \\ British Geological Survey, Keyworth, Nottingham NG12 5GG, UK \\ *Corresponding authors email address krro@bgs.ac.uk
}

\section{Abstract}

'Sustainable development' implies that a stable relationship between human activities and the natural world is possible such that the prospects of future generations do not diminish. Can this really be achieved in our urban centres where social and economic issues are often the driving force behind development and communal at the expense of comprehensive environmental issues? Geoscience information has traditionally been under-utilised in planning and development, because all too often its relevance and significance is misunderstood or underappreciated. However, this is starting to change. Using case studies from London and the Thames Gateway Development Zone, this paper discusses how technological developments, such as improvements in GIS technologies and 3D modelling software, are driving this turnaround. The paper also considers the impact of organisations not sharing ground investigation geodata and knowledge about anomalous ground conditions across London, the huge benefits that data sharing can offer and how lessons learned in this study can be applied to other urban centres. The paper will show that within the environmental ecosystem, if one component part is misunderstood, then developing sustainably without compromising future needs will be difficult, if not impossible, to achieve. In London, 
difficult ground conditions cost developers time and money through project overruns and expensive engineering solutions. A more sustainable solution is in improving our understanding of the relationship between the geology (lithology) and its properties (physical, chemical or hydrological characteristics). We will show that for the urban underground to be fully utilised throughout Europe, the lack of development policies for the subsurface needs to be addressed. For a subsurface development policy to be written, stakeholders will need to regard the urban underground as environmentally sensitive, just as it does for the surface.

Keywords: London, Urban Geology, Sustainable Development, 3D modelling 


\section{Introduction}

The European continent is the most urbanised continent with over $75 \%$ of its population living in urban centres, which occupy just $10 \%$ of the total land area (UNEP 2006). Urbanisation and its effects are therefore of significant importance to the continued social and economic development of the European Union. London is one of the most densely populated cities in Europe, with only Copenhagen, Brussels and Paris having higher densities (UNEP 2006). The London Plan (2008) predicts that the total population of London (currently at 8.2 million) will rise by 900,000 by the year 2016 (greater than the current population of Leeds). Furthermore, current projections for the years after 2016 show that London's population will continue to grow. A basic requirement for a city's continued growth is the availability of land, raw material and groundwater. Stanner and Bourdeau (1995) estimated that $2 \%$ of agricultural land is lost every 10 years due to urbanisation in Europe. This is not just due to development but also to land isolation, inefficient re-use of brownfield sites and contamination. Urban soils are themselves critical, in that not only do they provide green space but they also enhance air circulation, balance humidity levels and provide sinks for $\mathrm{CO}_{2}$ etc. Therefore, how do cities like London grow without expanding into the existing green belt or encroaching on internal green spaces?

The unprecedented demand for urban space in London due to population growth and a trend towards smaller households puts pressure on housing, transport systems and land prices. This has not gone unnoticed: in the Urban Task Force, 2005 report 'Towards a Strong Urban Renaissance', the group examined ways in which towns and cities can be revitalised and regenerated. Two key recommendations were given: firstly, better land utilisation, including underground 
space, and secondly the development of systems to encourage the regeneration of 'brownfield' sites. To the east of London is a 40-mile stretch of land along the River Thames. This region is an area of contrast, on the one hand containing areas with international and national conservation designations such as the Thames and Medway Marshes but on the other containing the largest collection of brownfield sites in Western Europe. This is a result of the closure of the area's main industries (such as docks, gas works and power plants). With the loss of the region's main employers, the area has also suffered from a high level of unemployment and deprivation (NAO 2007). There are approximately 212 major brownfield sites amounting to 4,597 hectares of brownfield land (ODPM and Roger Tym and Partners, 2002). If all this unused land were used to build houses, there would be enough space for 200,000 homes at a moderate density of less than 50 homes per hectare, thereby providing London with a solution to its current housing crisis and giving the region a chance to rejuvenate itself. "If we are to meet this housing need responsibly and sustainably, and provide for continued prosperity, we must seize the opportunity offered by this huge area of brownfield land and bring it back into productive use "(ODPM 2005).

The recognition of the region to the east of London as an area of substantial growth potential in the UK was documented in 1995. Its own sub-regional planning guidance (RPG9a) was published, and the Thames Gateway Development Zone was established. Shortly afterwards, the Department of the Environment, Transport and the Regions published a good-practice guide on the role of environmental geology in urban regeneration (Thompson et al. 1998). The report suggested ways in which economic and environmental initiatives might be complementary. The Thames Gateway offered a unique opportunity for the Government to put these ideals into 
practice. More information on these ideas and the vision behind the sustainable community plan for the Thames Gateway is set out in two reports; 'Creating Sustainable Communities: Making it happen: Thames Gateway and the Growth Areas' (ODPM 2003) and 'Creating Sustainable Communities: Greening the Gateway' (ODPM and DEFRA 2004). These reports paved the way for a raft of regeneration programmes and enterprises, including the Single Regeneration Budget, which sprung up in support of the Government's regeneration initiative.

When better utilisation of urban space is being considered in projects like the Thames Gateway, one direction that is often overlooked is that of the underground space. Within the Thames Gateway Development Zone, several major subsurface infrastructure projects have been and are being undertaken, such as the Jubilee Line extension, the Channel Tunnel Rail link and the Thames Tideway project. Underground development is considered to be high risk; however, it comes with massive advantages (Godard 2004) such as: efficient use of space, thereby relieving congested urban areas and preserving urban green spaces; the removal of unattractive buildings from the horizon; removing the need for external cladding, thereby reducing the material used and costs, and finally using the ground's natural ability to insulate and absorb heat and noise. However, as with many other urban centres in Europe, London suffers from an historic, uncoordinated proliferation of underground developments, which are unlike surface developments, where buildings can be demolished, thereby restoring the ground over time back to its original state. The underground is a finite resource, whereby every new development puts constraints on future developments. Therefore, although the urban underground provides a significant resource, the space it provides needs to be managed and controlled (Godard 2004). The development of underground space therefore requires 
a multi-disciplinary approach from urban planners, developers, regulators, architects, civil engineers, geotechnical engineers and geologists.

Within the Thames Gateway Development Zone social and economic needs are the main drivers for development. The Government has pledged that by 2016 the total number of new houses will rise to 160,000 , increasing by almost a quarter the number of people living in the region (ODPM 2005). With the speed of development taking place, the government facies a major challenges taking into account the environmental issues, including geological constraints if sustainable development is to be achieved. Can sustainable development be achieved? Within Government, the major controlling force behind the development of sustainable communities is the Department of Communities and Local Government (CLG). The release in March 2012 of the National Planning Framework (CLG 2012) sets out the UK Government's planning policy for development within England for the next 3 to 5 years. The framework puts sustainable development at the heart of the decision making process, setting sustainable criteria for development projects.

Sustainable development is a widely used term, having many different meanings (Hopwood et al. 2005). Put simply it can be defined as a pattern of economic development in which resource use balances human needs while preserving the environment, such that these needs can be met not only in the present, but also for succeeding generations. The concept of sustainable development formed from a growing awareness of the global links between environmental, socio-economic problems and the future of humanity. The term sustainability was used as early as the 1970s (Stivers 1976) but it wasn't until the World Conservation Strategy (IUCN et al. 1980) that sustainable development principles started to gain momentum. The Brundtland Commission and report 
(WCED 1987) recognised that humans depended on the environment, i.e. rather than dominating over nature, our lives, activities and society are nested within the environment (Giddings et al. 2002). Importantly, the Brundtland report defined sustainable development as the ability to meet the needs of the present without compromising the ability of future generations to meet their needs (WCED 1987). This marked the beginning of a new political and development paradigm, which for the first time reconciled the need for economic growth and environmental protection (UN 1997). The Brundtland report set out a concept for the integration of policy and decision-making in which environmental protection and long-term economic growth were not seen as incompatible but complementary. The UK Government's Sustainable Development Strategy 'Securing the Future' (2005) sets out to achieve just this through five 'guiding principles': living within the planet's environmental limits; ensuring a strong, healthy and just society; achieving a sustainable economy; promoting good governance, and using sound science responsibly.

Technological advances being made at the British Geological Survey (BGS), including the development of 3D geological modelling are making geoscience information more accessible for planners and developers and have enabled the British Geological Survey to develop a number of applications to assist with sustainable development. In this paper we will demonstrate how technological developments, such as improvements in GIS and 3D modelling software, have provided new insights into the geology under London. We will discuss the impact of organisations not sharing ground investigation geodata and knowledge about anomalous ground conditions across London. We will demonstrate that the most significant advances in urban geology in London have come about through 
collaboration and partnerships. Finally we will discuss how the lessons learned from this study could be applied to other urban centres.

\section{Anomalous Ground Conditions in London}

The intensity of development in London, coupled with its legacy of contaminated ground, demands for drinking water, vulnerability to rising sea levels, storm surge and size of population, all drive the need for establishing a geological model upon which planners, developers, engineers and insurers can rely (Royse et al. 2012). The infrastructure to support London makes it one of the most intensively investigated areas of shallow geology in the UK. However, construction work in London continues to reveal the presence of unexpected ground conditions (Royse et al. 2012). These anomalies have been discovered commonly on a local site specific scale but, due to the pressures of commercial work, are often recorded in confidential records with no further work to explain them. Before we consider the impact of geology on the development of London in the $21^{\text {st }}$ Century, we should look briefly at the geology of the region (for a more detailed description of the geology of London, see Royse et al. 2012).

Formations in London (Table 1) range from Cretaceous (144 to $65 \mathrm{Ma}$ ) to Quaternary (2 Ma to present day) in age. The Cretaceous Chalk is typically a fine grained white limestone. It has a total thickness of between 175 and $200 \mathrm{~m}$ and generally thins from west to east. Overlying the Chalk is the Palaeogene that comprises the Thanet Sand Formation, the Lambeth Group (consisting of the Upnor Formation overlain by a complex mix of various facies, attributed to the Reading and Woolwich Formations) and the Thames Group, which consists of the Harwich and London Clay Formations. Quaternary deposits are encountered throughout the 
London Basin. These include evidence of ancient river systems and the development of the present-day River Thames valley.

Traditionally, the geology in London has been considered to be 'relatively simple' (Sumbler 1996). However, from current engineering projects such as the Channel Tunnel Rail Link, Thames Water Ring Main (Newman 2009, Skipper et al. 2009), Crossrail (Warren and Mortimore 2003) and the Docklands Light Railway, there is a growing body of direct evidence which is challenging traditional concepts on the complexity and formation of the London Basin was formed (Royse et al. 2012). In the past, it was thought that the basin was formed during the Pleistocene. Yet work by Mortimer and Pomerol (1997) and Mortimer et al. (2011) shows that the Chalk was deposited syntectonically over faulted basement blocks and it is these faults that controlled both its lithology and thickness. Further evidence has been gathered from the alluvial deposits of the River Thames which show multiple structurally controlled off-sets and flow patterns (de Freitas 2009). A picture of the London Basin is emerging where fault movements occurred throughout the Cretaceous and Tertiary periods and have remained active to the present day. It is likely that continued fault movement will have divided the basin into sections. It is also probable that each section will have moved by different amounts both vertically and horizontally. It would follow that no rock unit in London can therefore be relied upon to have lateral or vertical continuity. The sudden change in conditions, in particular groundwater conditions, which faults can create has significant cost implications, particularly for sub-surface developments in London.

Of all the rock units in London, it is the intense variability of the Lambeth Group that gives rise to some of the most complex and challenging ground conditions for civil engineering works in London (Page and Skipper 2000). A better 
understanding of these deposits is critical for many current and future civil engineering projects, e.g. the Jubilee Line Extension (Bailey et al. 1999), the Channel Tunnel Rail Link (Dyke and Glover 2007) and the development of the Crossrail network (Heath 2001). The Lambeth Group are tidal flat deposits and, reflecting this depositional environment, contain numerous sand channels. These granular sand bodies can produce irregular groundwater flows when encountered particularly in tunnels and deep excavations, leading to instability at the tunnel face. The most famous case is the construction of the Thames Tunnel designed by Brunel, from Rotherhithe to Wapping and competed in 1843 (Hight et al. 2004). The initial ground investigation showed a significant thickness of clay, but borings ahead of the face demonstrated that the clay was not continuous. There were numerous collapse events during the construction phase. The most serious was caused the collapse of the overlying Upper Mottled Beds and inundation by river water, resulting in six fatalities. Issues with the ground works caused delays and resulted in the tunnel taking almost 20 years to complete.

Much of the Channel Tunnel Rail Link was, and the new Thames Tideway Tunnel will, however, be constructed in the Chalk. Although the Chalk itself provides a reasonable tunnelling medium, it is the flint bands (which occur in nodular and tabular forms) found within the Chalk that form considerable obstructions to ground investigations and cause excessive wear to tunnelling equipment. Avoiding these layers has substantial advantage in terms of both time and cost overruns (Mortimore et al. 2011). Tabular sheet flints can also significantly affect groundwater flows and frustrate de-watering if not accounted for (Lord et al. 2002). However, they are very difficult to recover during ground investigations and can often only be inferred from a zone of core loss. 
The thickness of river terrace deposits varies considerably within London (Berry 1979). Some of the largest 'anomalies' have been described as 'Drift Hollows' and are associated with an unexpected change in ground conditions, where deep hollows that can be up to $500 \mathrm{~m}$ wide and more than $60 \mathrm{~m}$ in depth are in-filled with disturbed superficial deposits and highly weathered bedrock (Ellison et al. 2004). Engineering works have encountered a numbers of these features during foundation excavations and in tunnelling projects, for example for the Victoria Line (Berry 1979) and the Blackwall Tunnel (Ellison et al. 2004). Hutchinson (1980) has suggested that many of these features could have originated as pingos, developed as a result of peri-glacial processes.

Why does such an intensively investigated area still have so many geological complexities that are so poorly understood? This is predominantly down to two issues: firstly, the fact that the bedrock is buried beneath Quaternary deposits and/or the built environment (Royse 2010), and secondly due to a lack of co-ordination and data-sharing between the engineering and geological communities (de Freitas and Royse 2009). Our ability to predict the impact of the ground on any development depends on the conceptual understanding of the subsurface and the effectiveness of the of ground investigations, which is ultimately controlled by the geology (Clayton et al. 1995). Issues with the interpretation of ground investigations for London can be put into three categories: incomplete data, generated by either the sampling regime or from drilling losses; erroneous data and finally, by using an oversimplified geological framework model. All of these contribute to the biggest risk for development projects in London, that of insufficient, inadequate andv incorrectly interpreted and modelled data. 


\section{The Solution}

When decisions are made as to the specifications and cost of development projects, organisations involved in the design and planning need easy access to a myriad of geoenvironmental information (Royse et al. 2009). Data generated by several large engineering projects, for example the 2012 Olympics, Jubilee line, Crossrail and the Channel Tunnel Rail Link have shown the value in having high quality, consistently logged and interpreted boreholes, along with associated sampling and testing that is all stored in a standard electronic data format. The format used in the UK is called AGS; it provides a medium for the fast electronic transfer of geotechnical and geoenvironmental data into a variety of industry standard software packages (AGS 2012). The AGS data format is an industry standard that has been around since the early 1990s. Unfortunately however, the adoption of AGS format is not yet universal. Where adopted, the AGS data format has enabled improved communication of geoenvironmental information between projects in the commercial sector, as well as allowing data to be transferred directly into the British Geological Survey national geotechnical and borehole databases (AGS 2012).

The availability of digital data is a major step forward. However, it is of little use if there is no consistency in the descriptions of geological units. Due to the problematic nature of the geology of London as described in the section above, the geoengineering and geotechnical industry needed a standardised approach to lithological and stratigraphical logging within London and the Thames gateway (Skipper 2008). Once this was achieved, geoscience professionals were able to start to compare geological information between sites and it was at this point that it became clear that the conceptual geological model needed to be modified to fit field 
observations (de Freitas 2009). The following sections outline the work carried out at the British Geological Survey. Each section describes how, by using digital data in geospatial modelling packages, it is possible to generate models that link geological history to accurate models of ground conditions and hence allow engineers to make more reliable predictions of engineering conditions (Royse et al. 2012).

\subsection{Detailed property modelling of the Thames Gateway model}

The Thames Gateway (TG) 3D model covers an area of $1800 \mathrm{~km}^{2}$ and has been built using GSI3D from over 4,000 boreholes at roughly 2 boreholes per $\mathrm{Km}^{2}$ and more than 200 north-south and east-west trending cross-sections (Royse et al. 2009). The model (Figure 2) was constructed using a generalised vertical section of the lithostratigraphy, which, when combined with the generated cross-sections and a Digital Terrain model DTM, created a fence diagram of the geology (Royse et al. 2009). To gain full value from the 3D geological model in the urban environment, bulk attribution of the model with engineering, geological and hydrological data was undertaken. The 3D model is attributed by assigning property values for each geological unit modelled (be that Group, Formation, Member or Bed). Bulk attribution provides a simple way of visualising the property characteristics of each geological unit modelled and their spatial relationships. The TG model was attributed with several datasets, which included engineering, geological classification, groundwater productivity and maximum and minimum permeability (Royse et al. 2009). The attributed model provided a platform for the integration and visualisation of data from diverse sub-disciplines. Considerable insights can be gained from bulk attribution, such as thickness of the unsaturated zone, the presence of perched water tables or the depth to good foundations. By incorporating a wide variety of hydrogeological 
information into the 3D geological model, it is possible to improve understanding and knowledge of groundwater systems thereby developing a better conceptual hydrogeological model for part of the TG (Royse et al. 2009). Further work is under way to model the full heterogeneity displayed within real geological systems by using voxel-attribution.

\subsection{Fault modelling in the London Basin}

As part of a major reassessment of how groundwater will be managed in London has been substantially, the groundwater model for London had to be updated. For this to be undertaken, a 3D model of the Chalk under London was required. The geological modelling had two key objectives: firstly, to ascertain the distribution of the six Chalk formations found within the London Basin and secondly, to elucidate the structure of the Chalk. One of the major difficulties with determining the structure of the Chalk is that the Chalk in London is largely unexposed and where it is exposed, it is either covered by superficial deposits (drift) or obscured from view due to urban development. Therefore, the project had to rely to a large extent on the geologist's interpretation of the subsurface data and geological observations made from the mid 1800s up to the present day. Although few faults are indicated on the current published geological maps, there is a growing body of data, particularly from recent deeper engineering projects such as the Channel Tunnel Rail Link (CTRL) (Harris et al. 1996) that suggests that faults are far more numerous. These data are further supported by the mounting evidence that tectonic and sealevel movement occurred in phases throughout the upper Cretaceous (Evans and Hopson 2000, Evans et al. 2003, Mortimore and Pomerol 1987, 1991, Mortimore et al. 1998). A methodology was developed that enabled the geologist to apply 
intuitively his geological knowledge to the 3D model. Therefore, the work-flow mirrored the methods used when drafting cross-sections across areas with sparsely distributed control data (Royse 2010). It was then possible to pick out areas of probable faulting and to achieve a geologically reasonable solution, even in areas where the data are sparse or uncertain (Kaufmann and Martin 2008, Lemon and Jones 2003). Once areas of faulting were picked out, the faults were then generalised into a coherent fault network and, using numerical techniques in GOCAD, the grids were smoothed and the model cut by the fault network generated (Royse 2010). The resultant model is more consistent with current geological observations and, as a consequence, is a closer representation of geological reality (Figure 3). For example, the model predicts that the Greenwich fault continues into north-east London and that there is faulting to the south of the River Lea. Ground investigations, including rotary cored boreholes, carried out as part of the Thames Tideway tunnelling project (Newman 2009) have shown that these predictions can be substantiated. Further evidence for validation of the modelling methodology has come from chalk-cored boreholes from the Thames Water's Lee Tunnel and Thames Water's Ring Main extension, where site investigations recently reported by Mortimore et al. (2011) suggest the presence of a major north-south offset which has again been predicted by this model. Current work under way on the production of a new hydrogeological model for London has found that, in using the new fault model, the resulting groundwater level pattern fits better with groundwater level observations made by the Environment Agency (EA 2012)

The Chalk model has led to a significant reduction in risk for the Environment Agency (EA). For example, in the London area, the EA grants licences for groundwater abstraction and a critical element of this is to ensure that the resource 
availability is managed effectively (DTZ 2011). The geological model and the associated hydrological modelling provided greater reliability in the measurement of water availability. As the EA decisions are risk- based, technical knowledge facilitates by up-to-date 3D modelling allows, supporting more informed decision-making. The economics of getting the decision making right is clearly evident, as an example, the commercial value of having an abstraction licence is between $£ 1$ million and $£ 1.5$ million per year for each Ml/d (million litres per day) on its licence. At the moment, about $270 \mathrm{Ml} / \mathrm{d}$ groundwater abstraction is licensed in London. Therefore, if an extra $10 \%$ were to be granted because of better technical knowledge, this would generate $27 \mathrm{Ml} / \mathrm{d}$, representing between $£ 27$ and $£ 40$ million extra income being generated in abstraction licensing for commercial business (DTZ 2011).

\subsection{D modelling of the Lambeth Group}

As described above, the Lambeth Group is a complex sedimentary assemblage (Knox 1996, Ellison et al. 2004). Although relatively thin (10 to $20 \mathrm{~m}$ in total thickness), it consists of three formations, divided into distinctive, named lithofacies (Ellison 1983; Ellison et al. 1994, 2004). The mainly shallow marine Upnor Formation is overlain by the terrestrial Reading Formation which passes into the intertidal Woolwich Formation. The Lambeth Group is most complex under central London (table 1), where it occurs at shallow depth. Therefore, a clearer understanding of these deposits has been crucial in recent major civil engineering projects, particularly those involving tunnelling, such as the Jubilee Line Extension (Bailey 1999); the Channel Tunnel Rail Link (Dyke and Glover 2007) and the development of the CrossRail network (Heath 2001). Over 1,400 digital site investigation borehole logs were used to review and modify the lithofacies maps of the Lambeth group (Ellison 
et al. 1994). These modified maps were then compared with newly modelled structures within the London area, as shown by 3D modelling of the Chalk under London (Royse 2010, Mortimore et al. 2011).

In central London, the base Palaeogene forms a structural high, subdividing the basin into two halves (Royse 2010, Figure 4). It was found that the Reading Formation occurs over the London culmination and to the west. Conversely, the Woolwich Formation is found over the London culmination and appears not to be present to either side, whereas the Upnor Formation, which consists of green glauconitic sands, is found predominantly in the east of the basin. This indicates that there was structural control on Lambeth Group deposition, whereby the structural high in central London has acted as a barrier, creating different environmental conditions in the eastern and western parts of the London Basin. Following on from this work, a full 3D model is being developed of the Lambeth Group under central London.

\subsection{Superficial Hollows and Rockhead anomalies hazard susceptibility model}

Engineering works carried out beneath London have unearthed a number of features which exhibit curious characteristics (Hutchinson 1991). These features, which can be up to $500 \mathrm{~m}$ wide and more than $60 \mathrm{~m}$ in depth (Ellison et al. 2004), extend deep into the Chalk bedrock and are in-filled with disturbed superficial deposits and highly weathered bedrock (Hutchinson 1991). Failure to identify these features can prove costly due to the associated presence of variable ground conditions and the potential to act as pathways for contaminant flow. In order to provide planners in London with a broad awareness of the potential location of these features a hazard susceptibility map was produced by the British Geological Survey 
(Banks et al. Submitted, Figure 5). A rule-based approach was adopted and four criteria were considered: proximity to the river network (within 300m of an existing or former river); areas of probable artesian groundwater conditions during the Devensian; below the Kempton Park river terrace deposit, and where clay rich bedrock units are less than $35 \mathrm{~m}$ thick (Banks et al. submitted). These criteria were identified on an assessment of information gained from the literature on the probable geological processes responsible for the formation of these features. Using ARC GIS, it was possible to develop 3 zones: Zone A, where all 4 criteria were met; Zone $B$, where 3 criteria were met and finally Zone $C$, where just 2 criteria were met. It was found that $81 \%$ of all known Superficial Hollows and Rockhead anomalies were found within Zones A and B (zone A having 52\% and zone B containing 29\%).

\subsection{Decision support tool for contaminant transport in the Lower Lea valley}

Another aspect of sustainable development is the prioritisation and remediation of contaminated land. The Initial Screening Tool (IST) was developed by the British Geological Survey to enable planners to assess the potential risk to ground and surface water due to remobilisation of contaminants by new developments, particularly in urban and peri-urban environments (Marchant et al. 2011). The IST is a custom-built GIS application that improves upon previous screening tools (Marchant et al. 2011) through the inclusion of 3D geological data and an enhanced scoring methodology tool. This is able to identify, track, map and score the potential risk from a source of contamination, along multiple possible pathways to potentially susceptible receptors. Furthermore, the IST is able to scrutinise the connectivity by generating cone-shaped zones of influence, rather than the more traditional method of using circular buffers, thereby attributing features 
within the direction of flow (Marchant et al. 2012, Figure 6). To provide connectivity between pathways and receptors, every surface water feature and aquifer is allocated a flow direction, so that potential contaminant migration is modelled only in the direction of flow. 3D geological and hydrogeological models have been developed for the whole of the Thames Gateway Development Zone (Royse et al. 2009). It was therefore possible to extract surfaces from given depths and incorporate them into the IST to allow for a more detailed analysis of the underlying geology. For example, the 3D model is used to identify low permeability interfaces; the IST is then able to consider successive formations with depth. A key requirement for the IST application was to make the tool simple to use and suitable for scenario planning. As a result, all rules and evaluation factors are held in Microsoft Access tables, making them straightforward to view and to edit. This gives the user the opportunity to investigate the effects of adding, removing or altering rules on the eventual outcome.

\section{Lessons learned for future Urban Geoscience projects}

It is clear that geology needs to be considered if sustainable development is to be achieved. Failure to understand the implications and the impact of geology on any development project will have a significant effect, not only on the initial cost of construction but also on the long term maintenance of the structure. Furthermore, better geotechnical knowledge assist environmental decision-makers, such as the EA, to make more informed decisions. It can be shown that just by improving the geological understanding within the groundwater model for London significant benefits can be gained (DTZ 2010). In London, past failure to share ground 
investigation geodata and knowledge about anomalous ground conditions limited the evolution of geological models and therefore the model failed to reduce the risk to engineering projects of unforeseen ground conditions, with a resultant increase in project costs.

The now-routine electronic capture of ground investigation data and the development of standardised data transfer formats such as AGS enable the fast and efficient transfer of geo-environmental information. This has given stakeholders in London several advantages: firstly, it has provided a way of sharing data that eliminates data transfer errors and secondly, it has encouraged better communication and collaboration between partners. When this capability has been combined with the cost of recreating geo-databases for every major engineering project undertaken (Hack 2009, Bonsor et al. 2012), stakeholders within London have had the impetus they need to start to share geodata. The value in having geoscientific information, therefore, is not in the possession of it, but in its amalgamation and interpretation.

In conjunction with this development has been the improvement in education and training of the borehole logging community. Much of the detailed lithological research presented in this paper could not have been undertaken if it was not for the high quality and consistency of borehole logging carried out in London (Skipper 2008). A key learning point has been that all borehole loggers (no matter who they work for) need to understand the geology that they are recording and the significance of what they are describing. To achieve this in London, a training programme has been developed which is becoming a requirement for loggers working on London geology. This has led to a huge improvement in borehole logging, 
which, most importantly, has then led to a better understanding of the ground and its behaviour.

Without these improvements to the geological model of London, unrealistic ground models and unreliable predictions (Wycisk et al. 2009) would have continued to prevail. The geological model serves as a base model from which all further models such as hydrological and geotechnical models are developed. If our conceptual understanding of the geological model is flawed, it follows that all modelling based upon it will also be flawed. It is only when all geo-information is collected together that a realistic model can be generated. Data, even when collected and presented, as in 3D models, still has to be interpreted, and it is clear that London lacked momentum in providing a sound basis for the interpretation of its geological data; hence, the anomalies and unexpected situations. To improve engineering and hydrogeological decision-making in London, the conceptual model needed to be updated, but this couldn't be achieved until a pathway was developed for academics and industry to communicate with one another.

There has in the past been a disconnection between academics and industry (Conway and Waage 2010) and part of the work undertaken by the British Geological Survey within London has been to break down those barriers. To develop and improve upon the geological model in London and to move forward to produce geodatasets tailored to stakeholders needs (such as the superficial hollow and rockhead anomalies susceptibility layer), partnerships with national and local stakeholders have to be developed. Historically, where research has been funded by national funding agencies, it has been the academics who have dominated the research agenda, with industrial partners being given minor roles, often on project boards. For these new partnerships to work there is a need to develop a much more equitable 
way of working, with genuine collaboration. To enable this forums and networks need to be supported and invested in. In London, the London Basin Forum supported by the Geological Society of London fulfils this role (de Freitas and Royse 2010). The Forum consists of a mixture of university academics, industry, the Environment Agency and the British Geological Survey; it is here, through yearly meetings and collaborative research projects, where the transfer of knowledge is taking place.

In this paper we have shown that, through advances in the ability of Geographical Information Systems (GIS) and 3D modelling packages which can handle large datasets on a regular desktop $\mathrm{PC}$, it has been possible to change the way that geo-environmental information is viewed, manipulated and interpreted. This has enabled the construction of the 'next generation' of geological models for London to start to take place. These models will provide a platform for integrating and visualising data from many different sub-disciplines, so allowing a model to portray some of the natural heterogeneity of geological systems. As with all models, the users must understand the limitations of the data on which they base their decisions (such as incomplete data coverage, data density, and erroneous data). This is becoming more critical as technological improvements are allowing geoscientists to introduce a far greater level of realism into their models.

Demands for space in the urban environment have resulted in some cities spiralling upwards, forming massive skyscrapers. Conversely, the urban underground's potential is yet to be fully realised in many cities. There are of cause exceptions to this, of which the best example is Montréal which has probably one of the largest underground cities in the world (Mulder et al. 2013).The potential space the urban underground could provide for burying car parks, transport networks and shopping centres etc. cannot be overlooked (Godard 2002). The possibility therefore 
exits of a future that would favour compact urban centres, resulting in more greenfields at the surface, an improvement in traffic conditions and a reduction in air pollution, resulting in a better quality of life. However, space is not the only resource that the underground provides us with; for example, cooling and heating systems, mineral and water resources. The sustainable utilisation of the urban underground is consequently a major challenge for the future.

Utilisation of the urban underground will necessitate 'multiple-use' planning, whereby the geological and environmental consequences are coupled with economic and social impacts. While rules exist for planning and resource management for surface developments, these rules are almost entirely absent for the subsurface (Huggenberger and Epting 2011). Mulder et al (2012) highlights this issue further stating that currently no county on earth has a legislative policy or management scheme in place in which the whole of the subsurface is integrated. This means that the interactions between different uses of the underground are at best inefficient and at worst could lead to sterilisation of the subsurface for future uses and increased subsidence and contamination risks. With subsurface development growing rapidly in some cities e.g. Qian and Chen (2007) expect the Beijing underground to triple in size by 2020 resulting in $20-30 \%$ of the total floor space within the central urban district to be underground, there will be a necessity for suitable planning frameworks to be developed. One way of achieving a more integrated planning assessment of the subsurface could be by utilising strategic environmental assessment tools (Bobylev 2004). This is further supported by Galipeau and Besner, (2003) who found that in Montréal successful development of the underground space had been achieved due to the integrated approach taken by developers and the positive interactions between the private and public sector. 
A major stumbling block to the multiple-use of the underground is the lack of an urban underground development policy for London. Without this policy, the urban underground will continue to be developed inefficiently, leading to significant constraints on its use in the future. The benefits of such policies can be seen in Helsinki where since 1984 all underground plans and activities by the city authorities and private companies has been coordinated allowing for a Underground Space Allocation Plan to be designed by the city planning department and 7 million $\mathrm{m}^{3}$ of underground space to be developed (ITA 2000, Chow 2002). An urban underground development policy should assess, at a minimum, four resource types: space, energy, water and mineral. A key reason for poor progress of such a plan has been the failure of all stakeholders to regard the underground environment as a critical aspect of policy development within our cities; instead, it is viewed as something that is only needed when there is a crisis. One solution could be to use 'environmental mainstreaming' (Conway and Waage 2010). Environmental mainstreaming encompasses the process by which environmental issues are brought to the attention of policy makers on a local and national level. This includes the involvement of a wide range of stakeholders during the policy-making process. Finally, environmental measures are developed and placed within the policy document itself.

\section{Conclusions}

Can sustainable development be achieved if geology is ignored?

Sustainable development can only be achieved if an appreciation of the close links between the environment and society are understood (Hopwood et al. 2005). 
These links are many and varied. In this paper we have shown that even within the environmental ecosystem, if one component part is misunderstood or misrepresented, then developing sustainably without compromising future needs will be difficult, if not impossible, to achieve.

In London, difficult ground conditions cost developer's time and money through project overruns and expensive engineering solutions. A more sustainable solution is in improving our understanding of the relationship between the geology (lithology) and its properties (physical, chemical or hydrological characteristics). It has been shown that unless the geological model is continually improved upon, it will produce unrepresentative ground models and unreliable predictions. Although London is one of the most intensively investigated areas of ground in the UK, construction work continues to expose unexpected ground conditions. In the past, a lack of co-ordination and data-sharing between the commercial sector and the wider geological community had meant that the conceptual geological model had not been updated. With the engagement of stakeholders through forums and networks, equitable partnerships have now been set up and the next generation of geological models and decision support tools are now being developed.

It can be shown, that although advances in 3D modelling and GIS technologies have improved the way that geodata can be manipulated and displayed, these technological advancements alone have not provided the whole solution and should not be viewed as a 'silver bullet'. Communication and collaboration between stakeholders within the urban environment is equally important, if not more so. It is only when true engagement between all partners is gained that sustainable development can be delivered. 
Finally, for the urban underground to be fully utilised throughout Europe, the lack of development policies for the subsurface needs to be addressed. For a subsurface development policy to be developed, stakeholders will need to regard the urban underground as environmentally sensitive, just as it does for the surface. The subsurface provides a unique but finite resource where, unlike developments on the surface that can be demolished and rebuilt, every new development puts constraints on future developments. Therefore, not only does the development of the urban underground need to be managed but it also requires a multi-disciplinary approach to the planning process.

\section{Acknowledgements}

This paper is published with the permission of the Executive Director of the British Geological Survey (NERC)

\section{References}

AGS. (2012): Electronic transfer of geotechnical data from ground investigations (3rd Edition). The Ass. Geotech. \& Geoenvir. spec. Beckenham, Kent (http://www.ags.org.uk/)

Bailey, D. (1999): Jubilee Line extension - Foreword. Proceedings of the Institution of Civil Engineers. - Civil Eng. 132: 3-3.

Bailey, R.P., Harris, D.L. \& Jenkins, M.M. (1999): Design and construction of Westminster station on the Jubilee Line Extension. - Proc. Inst. Civil Eng.132, 36-46. 
Banks V.J., Bricker S H, Royse K.R. \& Collins, P.E.F. (sub): Development of a Hazard Susceptibility Map for Superficial hollows and rockhead anomalies in London. - Quart. J. Eng. Geol. Hydro.

Berry, F.G. (1979): Late Quaternary scour hollows and related features in central London. Quart. J. Eng. Geol. 12, 9-29.

Bobylev, N. (2004): Comparative risk assessment and environmental impact assessment: similarly in quantitative methods. In Linkov, I and Ramadan A (ed): Comparative Risk Assessment and Environmental Decision Making. Kluwer.

Bonsor, H., Lawrie, K., Watson, S., Campbell, D., Lawrence, D., Hall, I., Hay, D. \& Barron, H. (2012): Transforming the exchange of subsurface data and knowledge between the public and private sectors : a pilot in Glasgow, UK. [Poster] In: 7th EURGEO EUropean congress on REgional GEOscientific cartography and Information systems, Bologna, Italy, 12-15 June 2012

Chow, F.C. (2002): Underground space: the final frontier? - Ingenia infrastruct. 14: 15-20

Clayton, C.R.I., Matthews, M.C. \& Simons, N.E., 1995. Site Investigation. Blackwell.

CLG. (2012): The national Planning Policy Framework. Department for Communities and Local Government. HMSO. London.

Conway, G and Waage, J. (2010): Science and Innovation for Development. UK Collaborative on Development Sciences.

de Freitas, M.H. (2009): Geology; its principles, practice and potential for Geotechnics. Quarterly J. Eng. Geol. Hydro. 42, 397-441.

de Freitas, M. \& Royse, K.R. (2009): London Basin Forum. - Geosci. 19: 20-21.

Dyke, A., Glover, M. (2007): Channel tunnel rail link section 2: introduction. - Proc. Inst. Civil Eng.160, 3-5.

DTZ. (2011): Modelling the UK in 3D. NERC Impact Study. (http://www.nerc.ac.uk/business/casestudies/documents/modelling-uk-3d-report.pdf)

Environment Agency. (2012): Management of the London Basin Chalk Aquifer. Environment Agency. London. 
Ellison, R.A., Knox, R.W.O., Jolley, D.W. \& King, C. (1994): A revision of the lithostratigraphical classification of the early Palaeogene strata of the London Basin and East Anglia. - Proc. Geol. Ass. 105: 187-197.

Ellison, R.A., Woods, M.A., Allen, D.J., Forster, A., Pharaoh, T.C. \& King, C. (2004): Geology of London. Special Memoir for 1:50 000 Geological sheets 256 (North London), 257 (Romford), 270 (Dartford) (England and Wales) British Geological Survey.

Erratt, D., Thomas, G. \&Wall, G. (1999): The evolution of the Central North Sea Rift. In: Fleet, A., Boldy, S. (ed.): Petroleum Geology of Northwest Europe: Proceedings of the 5th Conference. - Geol. Soc. Lond. 63-82.

Evans, D.J. \& Hopson, P.M. (2000): The seismic expression of synsedimentary channel features within the chalk of southern England. - Proc. Geol. Ass. 111 (3): 219-230.

Evans, D.J., Hopson, P.M., Kirby, G.A. \& Bristow, C.R. (2003): The development and seismic expression of syn-sedimentary features within the chalk of southern England. - J Geo. Soc. 160: 797-813.

Ford, J., Mathers, S., Royse, K.R., Aldiss, D. \& Morgan, D.J.R. (2010): Geological 3D modelling: scientific discovery and enhanced understanding of the subsurface, with examples from the UK. - Z. Dt. Ges. Geowiss.161: 205-218.

Galipeau, G \& Besner, J. (2003): The underground city of Montreal: a win-win approach in the development of a city. Presentation at the $1^{\text {st }}$ international conference 'sustainable development and management of the subsurface. Utrecht, the Netherlands.

Giddings B., Hopwood B. \& O'Brien G. (2002): Environment, economy and society: fitting them together into sustainable development. - Sus. Dev. 10: 187-196.

Godard J.P. (2004): Urban underground space and benefits of going underground. World Tunnel Congress 2004 and 30 ${ }^{\text {th }}$ ITA General Assembly - Singapore, 22-27 May 2004.

Hack, R. (2009): Advances in the use of geodata for the urban environment. - In Culshaw, M.G., Reeves, H.J., Jefferson, I. \& Spink, T.W. (ed.): Engineering for Tomorrows Cities. Geol. Soc. Lond. Eng. Geol. Spec. Pub. 22: 201-207 
Harris, C.S., Hart, M.B., Varley, P.M. \& Warren, C.D. (1996): Engineering Geology of the Channel Tunnel. Thomas Telford Publishing, London, UK.

Heath, D.L. (2001): Crossrail: introduction. - Proc. Inst. Civil Eng. 147: 59-60

Hight, D.W., Ellison, R.A. \& Page, D.P. (2004): Engineering in the Lambeth Group. Publication C583. CIRIA. London.

Hopwood, B., Mellor, M. \& O’Brien, G. (2005): Sustainable Development: Mapping Different Approaches. - Sus. Dev. 13: 38-52

Hutchinson, J.N. (1991): Periglacial and slope processes. - Geol. Soc. Lond. Spec. Pub. 7: 283331.

Hutchinson, J.N. (1980): Possible late Quaternary pingo remnants in central London. - Nature. 284: 253-255.

Huggenberger P \& Epting J. (2011): Urban Geology: Process-Orientated Concepts for adaptive and integrated Resource Management. Springer. Basal.

ITA. (2000): Planning and Mapping of Underground Space - an overview. Working Group No4, international tunnelling association. - Tun. \& Ungrd. Sp. Tech. 15: 271-296

IUCN, UNEP, \& WWF. (1980): World Conservation strategy: living resource conservation for sustainable development. IUCN: Gland, Switzerland.

Kaufmann, O. \& Martin, T. (2008): 3D geological modelling from boreholes, crosssections and geological maps, application over former natural gas storages in coal mines. - Comp. \& Geo. 34: 278-290.

Knox, R.W.O. (1996): Tectonic controls on sequence development in the Palaeocene and earliest Eocene of south-east England: implications for North Sea stratigraphy. - In Hasselbo S.P. \& Parkinson, D.N. (ed.): Sequence stratigraphy in British Geology. - Geol. Soc. Lond. Spec. Pub. 103: 209-230.

Lemon, A.M. \& Jones, N.L. (2003): Building solid models from boreholes and user defined cross sections. - Comp. \& Geo. 29: 547-555.

Lord, J.A., Clayton, C.R.I. \& Mortimore, R.N. (2002): Engineering in Chalk. CIRIA. London 
Marchant, A., Banks, V.J., Royse, K.R. \& Quigley, S.P. (2013): The Development of a GIS methodology to assess the potential for water resource contamination due to new development in the 2012 Olympic Park site, London. - Comp. \& Geo. 51: 206-215

Marchant, A.P., Banks, V.J., Royse, K.R., Quigley, S.P. \& Wealthall, G.P. (2011): An Initial Screening Tool for water resource contamination due to development in the Olympic Park 2012 site, London. - Envir. Earth. Sci. 64: 483-495.

Mortimore, R., Newman, T.G., Royse, K., Scholes, H. \& Lawrence, U. (2011): Chalk: its stratigraphy, structure and engineering geology in east London and the Thames Gateway. Quart. J. Eng. Geol. \& Hydro. 44: 419-444.

Mortimore, R.N. \& Pomerol, B. (1987): Correlation of the upper cretaceous white chalk (Turonian to Campanian) in the Anglo-Paris Basin. - Proc. Geol. Ass. 98: 97-143.

Mortimore, R.N. \& Pomerol, B. (1991): Stratigraphy and eustatic implications of trace fossil events in the upper cretaceous chalk of Northern Europe. - Palaios 6: 216-231.

Mortimore, R.N. \& Pomerol, B. (1997): Upper Cretaceous tectonic phases and end Cretaceous inversion in the chalk of the Anglo-Paris basin. - Proc. Geol. Ass. 108: 231-255.

Mortimore, R.N., Wood, C.J., Pomerol, B. \& Ernst, G. (1998): Dating the phases of the Subhercynian tectonic epoch: Late cretaceous tectonics and eustatics in the cretaceous basins of northern Germany compared with the Anglo-Paris Basin. - Zen. Fur Geol. \& Palao. $1(11-12): 1349-1401$.

Mulder, E.F.J., Hack, H.R.G.K. \& Van Ree, C.C.D.F. (2012): Sustainable Development and Management of the Shallow Subsurface. Geological Society, London.

NAO. (2007): The Thames Gateway: Laying the Foundations. ISBN: 9780102945263. HMSO. London.

Newman, T. (2009): The impact of adverse geological conditions on the design and construction of the Thames Water Ring Main in Greater London, UK. - Quart. J. Eng. Geol. \& Hydro. 42: $5-21$. 
Newman, T. (2009): The impact of adverse geological conditions on the design and construction of the Thames Water Ring Main in Greater London, UK. - Quart. J. Eng. Geol. \& Hydro. 42 (1): 5-21.

ODPM \& DEFRA. (2004): Creating sustainable communities: Greening the Gateway. Implementation plan. HMSO. London.

ODPM \& Roger Tym and Partners. (2002): Review of Thames Gateway. HMSO. London

ODPM. (2005): Creating Sustainable Communities - delivering the Thames Gateway. HMSO. London.

ODPM. (2003): Sustainable communities: making it happen: Thames Gateway and the Growth areas. HMSO. London.

Page, D. \& Skipper, J. (2000): Lithological characteristics of the Lambeth Group. - Grd. Eng. 33: $38-44$.

Qian, Q. \& Chen, X. (2007): Evaluation of the status quo and outlook of the urban underground space development and utilization in China. - In Kaliampakos, D. \& Benardos, A. (eds): Underground space: expanding frontiers. - Proceedings of the $11^{\text {th }}$ ACUUS international Conference NTUA Athens, Greece. 15-21.

Royse, K.R., Rutter, H. \& Entwisle, D. (2009): Property attribution of 3D geological models in the Thames Gateway, London: new ways of visualising geoscientific information. - Bull. Eng. Geol. \& Envir. 68:1-16.

Royse, K.R. (2010): Combining numerical and cognitive 3D modelling approaches in order to determine the structure of the Chalk in the London Basin. - Comp. \& Geo. 36: 500-511.

Royse, K.R., de Freitas, M., Burgess, W.G., Cosgrove, J., Ghail, R.C., Gibbard, P., King, C., Lawrence, U., Mortimore, R.N., Owen, H. \& Skipper, J. (2012): Geology of London, UK. Proc. Geol. Ass. 123: 22-45.

Royse, K.R., Kessler, H., Robins, N.S., Hughes, A.G. \& Mathers, S.J. (2010): The use of 3D geological models in the development of the conceptual groundwater model. - Z. Dt. Ges. Geowiss.161: 237-249.

RPG 9a. (1995): The Thames Gateway Planning Framework. HMSO. London 
Skipper, J.A. (2008): Project Specific Geological Training - A New Tool for Geotechnical Risk Remediation. Euroengeo International Association of Engineering Geology, Madrid.

Skipper, J. A. (1999): The Stratigraphy of the Lambeth Group (Palaeocene) of South East England. PhD, Imperial College London.

Skipper, J.A., Newman, T., Mortimore, R.N. (2008): The Engineering Geology of the Lee Tunnel, East London, UK. Euroengeo International Association of Engineering Geology, Madrid.

Stanners, D. \& Bourdeau, P. (1995): Europe's Environment - The Dobris Assessment, Earthscan Publications, London, UK.

Stivers, R. (1976): The Sustainable Society: Ethics and Economic Growth. Philadelphia: Westminster Press

Sumbler, M.G. (1996): British Regional Geology: London and the Thames Valley, 4th edition. British Geological Survey, London.

The Mayor of London. (2008): The London Plan: Spatial development strategy for Greater London. Consolidated with alterations since 2004. Greater London authority.

The UK Government. (2005): Securing the Future. The UK Government sustainable development strategy. HMSO. London.

Thompson, A., Hine P. D., Grief, J. R. and Poole, J. S. (1998): Environmental geology in Land Use and Planning: Advice for Planners and developers. Report to the Department of the Environment. London.

United Cites and Local Governments, Culture: Fourth Pillar of Sustainable Development.

United Nations. (1987): Report of the World Commission on Environment and Development. General Assembly Resolution 42/187, 11 December 1987. Retrieved: 2007-04-12

UNEP. (2006): Global Environment Outlook Year Book 2006: an overview of out changing environment. Progress Press Ltd. Malta.

Urban Task Force (2005): Towards a strong Urban Renaissance. (http://www.urbantaskforce.org/UTF final report.pdf) 
Warren, C.D. and Mortimore R. N. (2003). Chalk engineering geology - Channel Tunnel Rail Link and North Downs Tunnel. Quart. J. Eng. Geol. \& Hydro. 36 : 17-34

World Commission on Environment and Development (WCED). (1987): Our Common Future. Oxford University press. Oxford.

Wycisk, P., Hubert, T., Gossel, W. \& Neumann, C. (2009) High-resolution 3D spatial modelling of complex geological structures for an environmental risk assessment of abundant mining and industrial mega-sites. - Comp. \& Geo. 35: 165-182.

\section{Figures}

Figure 1: A: Geological sketch map of project area. Adapted from Sumbler (1996) B: location map indicating where some of the most recent major infrastructure development projects are taking place in London

Figure 2: An illustrative example of a 3D geological model produced for the Thames Gateway Development Zone, covering an area from the Thames Estuary to the Lower Lee Valley (Olympic park 2012 site). Diagram is displayed at 10 times vertical exaggeration. Key to colours used for lithological units are as follows: peat (brown), alluvium (yellow), river terrace deposits (orange) and anthropogenic deposits (grey). Bedrock is composed of Palaeogene deposits (orange, blue and pink) underlain by Chalk (green) (adapted from Royse et al. 2012).

Figure 3: 3D model of Chalk Group under London (adapted from Royse 2010). Diagram is displayed at 10 times vertical exaggeration. Each layer represents a subdivision of the Chalk 
Group, seaford and Newhaven chalk Formations undivided (light green)arre underlain by the Lewes Nodular Chalk Formation (mid green), New pit Chalk Formation (dark green), Holywell Chalk Formation (Orange), Zig Zag Chalk Formation (blue) and finally at the base West Melbury Chalk Formation (yellow). Contains Ordnance Survey data @ Crown Copyright \& Database rights 2012. Licence No. 100021290

Figure 4: A: distribution of the Lower Shelly Clay of the Lambeth Group (blue); overlain on monochrome shaded relief map of the base of the Palaeogene (adapted from Ford et al., 2010). Inset is a structure contour plot (red high, blue low) of the base of the Palaeogene showing the major fault groups as defined by Royse (2010) and the location of a structural high located over central London

Figure 5: Zoned Superficial Hollows and Rockhead anomalies hazard susceptibility map (adapted from Banks et al., submitted). Contains Ordnance Survey data @ Crown Copyright \& Database rights 2012. Licence No. 100021290

Figure 6: Modelling Pollutant Linkages using the Initial Screening tool (IST). The diagram shows how individual pollutant linkages are established by defining a source zone of influence around the source site. The GIS is then interrogated to establish whether the zone of influence intersects either surface water or an aquifer and then whether a susceptible receptor is within the zone of influence. In this diagram a pollutant source (a factory) has a zone of influence (red) calculated by the GIS system (yellow arrows show direction of fluid movement). This zone of influence intersects with a river which provides a pathway between the factory and a groundwater aquifer (outlined in light blue). A zone of influence (Red) is again generated by the GIS system which establishes that a receptor, (a water well) is susceptible to pollution (adapted from Marchant et al. 2011) 


\section{Table}

Table 1: Summary of the geological strata of the London Basin adapted from Ellison et al (2004), Skipper (1999) with Chalk Group thickness updated from Royse et al. (2010) 